\title{
FINANCIAL CONTROL AND THE EMPLOYER OF LAST RESORT
}

\section{JAN TOPOROWSKI}

The School of Oriental and African Studies (SOAS), University of London, Economics Department, Thornhaugh Street, London WC1H 0XG, UK. ORCID: 0000-0001-8065-7157, Email: jt29@soas.ac.uk

\begin{abstract}
This paper examines the policy that has been suggested to resolve involuntary unemployment by having the government employ any persons who register as unemployed. This policy is compared to the full employment proposal of Michał Kalecki. Kalecki's proposals also contained a strategy for financing full employment. Like the Employer of Last Resort proposal, Kalecki's strategy allows employment policies to be examined from financial control, rather than the usual approaches of examining the impact of employment policy on labour productivity, or inflation, although both come into the analysis. The paper, therefore, outlines the proposal for an employer of last resort, and the proposed financing of that policy. A second part looks at Kalecki's proposals for full employment and its financing. A third part then considers the impact of the employer of last resort policy on financial stability.

KEYWORDS: Job Guarantee, full employment, Michał Kalecki, financial control, Modern Money Theory
\end{abstract}

\section{THE EMPLOYER OF LAST RESORT}

The employer of last resort (or Job Guarantee) is a policy or programme that is associated with Modern Money Theory, propounded by The Levy Economics Institute of Bard College, and the Economics Department of the University of Missouri Kansas City. In this programme, the government guarantees to provide a job for anyone willing to work, but unable to find a job in the labour market. The idea is superficially attractive: to realise the full employment that free-market capitalism seems unable to achieve. The proponents of the policy, mainly in the United States, present it as an extension, and realisation, of previous commitments to full employment that have been a staple of politics since the second half of the nineteenth century. The financing 
is also relatively simple and, on the face of it, attractive: the government would be able to pay for the programme with the savings from eliminating unemployment insurance, which would now be unnecessary. According to one of its leading advocates, the additional cost to the government of the programme would amount to 1 or $2 \%$ of Gross Domestic Product, which the government could obtain, following the principles of Modern Money Theory, by borrowing from the central bank. This minor cost would be more than outweighed by the social benefits of helping to eliminate poverty, providing economic security, and raising productivity (Wray 2011).

In the current political idiom, 'what is there not to like about this?' In its terms, the proposal offers social and economic benefits at a negligible cost. So, in a democratic society, if sufficient people are convinced, we can have all these benefits at minimal cost, without the social, political and intellectual disruptions that accompany revolutionary social progress. However, the association of the Employer of Last Resort proposal with Modern Money Theory reveals something else about the proposal, namely its political appeal that requires a minimal understanding of economics or monetary theory.

This aspect of the proposal, and other, similar proposals, was explored in the 1930s, as the world sank into the economic depression of the 1930s, in a volume of essays that the socialist economist and academic G.D.H. Cole put together, entitled What Everybody Wants to Know About Money: A Planned Outline of Monetary Problems. The essays were by colleagues from Oxford University, of whom one, Hugh Gaitskell, was to become famous as a leader of the Labour Party after the resignation of Clement Attlee in 1955. Gaitskell contributed to the volume an essay on 'Four Monetary Heretics' that explains directly and plainly the attractions of monetary innovations in crisis and showed the link between simple ideas and the populist mood of his time and ours. He defined his monetary 'heretics' as public figures who disagree in general with economists and have never held academic appointments in economics. His four heretics were Major Douglas, Professor Frederick Soddy, Silvio Gesell, and Robert Eisler. Soddy was the only academic, a Fellow of the Royal Society, and a Nobel Laureate in Chemistry in 1921. Gaitskell concluded that the success of monetary heretics lies precisely in their recognition of what is evident to non-economists:

... the heretic can claim that he is a practical man in touch with the realities of economic life and vitally interested in its reform, not content to toy with abstractions behind the shelter of a professorial salary. From his position he sees the depression as the general public sees it, as a paradox, as something not to be tolerated, as a problem for which there cannot conceivably be no solution, as a problem which can be solved at once. To plain man and heretic alike, the natural limitation to material welfare is primarily technical. That, quite apart from this, there should be almost as inevitable and difficult a problem of organisation, of social relations, is a vision confined as a rule to the expert who has to handle it...

... A unique master stroke is required. There is to be no painful waiting, no lowering of standards, no difficult compromises, no social upheaval, but simply the adoption of the one perfectly simple, perfectly feasible PLAN... 
The attraction lies not just in the simplicity of the PLAN:

... the heretic is able to enlist support just because he is not an expert, just because he represents and expresses the common dislike against the expert. He is a plain practical man, proving to other plain practical men that the mysteries which these exalted intellects are alone suffered to understand are matters which can be made perfectly intelligible to the rest of the community. Thus he restores the public's self-respect.

Gaitskell denied any intention to suppress such heresies: '.. it is of the utmost importance that every individual should be free to express himself on economic affairs. The plain man's instinct is in this case right. Economic experts can never be wholly trusted, and only with the utmost possible freedom criticism and construction can rapid scientific progress be made.' (Gaitskell 1933: 412-413). ${ }^{1}$

What is unusual about the Employer of Last Resort proposal, and the Modern Money Theory that stands behind it, is that the proponents of the proposal and the Theory are not amateurs, but a hedge fund manager and men and women with PhDs in Economics. They offer to the 'plain man' a 'Plan' that does not require any more profound understanding of how the economy works. This is the advantage of that 'Plan' in popular discourse. However, can it survive a closer examination by comparison with a proposal coming from a more sophisticated consideration of how the economy works? Here it is useful to compare the proposal with Kalecki's strategy for full employment.

\section{THE KALECKI PLAN}

Kalecki's plan for eliminating unemployment was presented in what is perhaps his most widely read paper, Political Aspects of Full Employment. Characteristically, he prefaced his lecture with an explanation of how full employment was to be financed. That explanation he included in the version that was published in the Political Quarterly. Nevertheless, he deleted it in the shortened version, published in Polish in 1961, and in the version, he subsequently authorised for publication in English in 1970 (Osiatyński 1990: 566-572). Acknowledging that the public financing of full employment was widely regarded as the chief obstacle to full employment, the reader was invited to imagine that the government pays its suppliers in interest-bearing government securities. The suppliers, of course, do not retain the securities but use them to pay for supplies that they buy. In this way, the new securities circulate until they fall into the possession of persons or firms that will retain them to maturity. The total value of securities held in the private sector will finance the government programme for obtaining full employment. In reality, the government pays for the services, not in securities but cash, but it simultaneously issues securities and so drains the cash off;

\footnotetext{
${ }^{1}$ It was this phrase that Keynes echoed, perhaps unconsciously, in his General Theory, where he remarked that 'the brave army of heretics', including Douglas, Bernard Mandeville, Thomas Malthus, Gesell and John A. Hobson '... following their intuitions, have preferred to see the truth obscurely and imperfectly rather than to maintain error, reached indeed with clearness and consistency and by easy logic, but on hypotheses inappropriate to the facts' (Keynes 1936: 371).
} 
and this is equivalent to the imaginary process described above' of paying suppliers with securities (Kalecki 1943).

There were three possible objections to this kind of financing. A practical one arises if the public were unwilling to hold the increase in government securities. Kalecki answered that the public would then offer them to banks in exchange for cash in the form of banknotes or bank deposits. If the banks accepted the securities at face value, then the government's rate of interest will be maintained. If, however, the banks do not wish to accept the securities at their face value, then the price of the securities will fall. This will mean an increase in the rate of interest, which will make it more attractive to hold the securities relative to deposits. 'It follows that the rate of interest depends on banking policy, in particular on that of the central bank. If this policy aims at maintaining the rate of interest at a certain level, that may be easily achieved, however large the amount of government borrowing. Such was and is the position in the present war. Despite astronomical budget deficits, the rate of interest has shown no rise since the beginning of 1940' (Kalecki 1943).

The second objection was that government expenditure might cause inflation. Kalecki countered this by pointing out that this is unlikely to happen as long as labour, plant and raw materials are available. Prices would only start to rise if demand exceeded available resources, for example, if government intervention continued after full employment had been achieved. According to him, this is not a problem specific to government intervention, since such inflation could also arise in the course of a private sector investment boom.

The third objection arose from the financing of the continually rising government debt if full employment is secured by deficit financing. Kalecki's solution to this was a capital levy or wealth tax, which he had earlier shown would not affect profits and hence, business investment or capitalists' consumption. The levy could be used to cover the servicing costs (interest and debt repayments) on government debt, giving all the benefits of fiscal stimulus without any of the disadvantages of government indebtedness (Kalecki 1943. Kalecki's capital levy is outlined in his paper A Theory of Commodity, Income and Capital Taxation Kalecki 1937).

Having shown how full employment may be achieved and financed, Kalecki dismissed the remaining economic arguments as coming from 'prominent so-called "economic experts" closely connected with banking and industry', thereby indicating that their 'economic' objections were really political. There is a paradox here since higher output and employment also benefits entrepreneurs, as well as workers. Kalecki argued that the remaining objections to full employment were motivated by three considerations. First of all, there was a dislike of business leaders for state interference in their employment practices. In a free market system, the level of employment depends on the amount of investment in the economy. That investment, in turn, reflects 'the so-called state of confidence' of businessmen. Any decline in that confidence results in a fall-off in investment, causing a fall in output and employment. "This gives the capitalists a powerful indirect control over government policy: everything which may shake the state of confidence must be carefully avoided because it would cause an economic crisis." However, if the government can regulate the level of employment by 
its own fiscal policy, then business circles lose their influence in government. "Hence budget deficits necessary to carry out government intervention must be regarded as perilous. The social function of the doctrine of »sound finance« is to make the level of employment dependent upon the state of confidence” (Kalecki 1943).

The second reason for a business to dislike full employment secured by government policy is because of the fiscal programmes by which full employment is secured. Where these compete with private enterprise, government investment reduces the profitability of private competitors. The government may even be tempted to nationalise transport or public utilities (as was done in Britain after the Second World War) to provide scope for public investment. One alternative is for government to subsidize mass consumption, by means of welfare payments, pensions, family allowances, or subsidies to maintain low prices of basic necessities. This, of course, does not enter into competition with private sector provision. Nevertheless, it challenges the moral principles of capitalist labour. In an unconscious echo of Veblen, Kalecki observed "the fundamentals of capitalist ethics require that "you shall earn your bread in sweat« unless you happen to have private means".

The third political objection arises from the social and political consequences of maintaining full employment. In a permanent state of full employment, labour would no longer be disciplined by the threat of firing workers: "The social position of the boss would be undermined, and the self-assurance and class-consciousness of the working class would grow. Strikes for wage increases and improvements in conditions of work would create political tension. With lasting full employment, profits would be higher than under laissez-faire, and even higher wages, due to the stronger position of workers in the labour market, would squeeze rentier incomes, rather than profits. But business leaders prefer labour discipline and "political stability« to higher profits in general. Their 'class instinct tells them that lasting full employment is unsound from their point of view, and that unemployment is an integral part of the "normal « capitalist system" (Kalecki 1943).

Kalecki then considered the situation under fascism, where capitalist objections to full employment are removed by concentrating government expenditure on armaments and maintaining labour discipline and 'political stability' by suppressing trades unions and imprisoning internal 'enemies' of the 'new order'. Expanding armaments production and the numbers of men in uniform with deadly equipment to hand induces competitive military investment in other countries. As shortages of capacity and equipment arise, it becomes necessary to plan the economy. But this is not socialist planning. Under fascism, planning is done by 'a partnership of big business and fascism', concentrated on the armaments sector, and at the expense of mass consumption. It 'ends inevitably in war.'

In 'a capitalist democracy', Kalecki was optimistic that the opposition of business leaders to full employment would be overcome. The experience of the 1930s had exhausted that opposition; the organisation of the war effort showed that full employment was possible; there was widespread social opposition to any return to unemployment. The only question was what should be done to prevent unemployment, and whether it should only be done in a slump in preference to measures that would secure 
permanent full employment. Business would prefer reliance on private investment because this would leave business people in control of the full employment policy. However, interest rate and income tax reductions could not maintain full employment in the long run, because such reductions would then have to be cumulative. So, private investment would need to be reinforced by public investment, if not subsidizing consumption.

Kalecki argued that the inherently political controversies around full employment would give rise to a political business cycle. In a slump, with large-scale unemployment, the government would undertake debt-financed investment. But, as the boom proceeds, opposition would arise from business leaders anxious about the effects of full employment on labour discipline, while rising prices in the boom would squeeze the real incomes of rentiers making them 'boom-tired'. 'In this situation a powerful alliance is likely to be formed between big business and rentier interests, and they would probably find more than one economist to declare that the situation is manifestly unsound.' The alliance would force the government to return to fiscal orthodoxy. As a result, the economy would decline into recession. At this point, full employment policies are resumed. It is worth noting that this had already happened in the United States in 1937-38, when a drastic reduction in the federal budget deficit had broken the economic recovery. However, the resulting recession had forced the government to return to the previous programme of fiscal stimulus. The political business cycle would be a milder version of the nineteenth-century capitalist business cycle. Full employment would only be reached at the peak of the boom. However, recessions would be comparatively modest and short.

Kalecki concluded by asking whether someone of a progressive outlook should be satisfied with such a regime of modest economic fluctuation just below the level of full employment. He answered that a progressive should oppose it because it does not assure permanent full employment and because the government spending is restricted to public investment, and does not include subsidizing consumption, with welfare payments. Kalecki suggested that beyond a certain point, public investment could be excessive, resulting in unwanted projects, just for the sake of providing work. To the objection that "the government will have nothing to show for their money" in subsidizing consumption, he answered that such subsidies would provide a higher standard of living for the population and asked rhetorically "is not this the purpose of all economic activity?” (Kalecki 1943: 330).

Finally, Kalecki argued that if capitalism can accommodate full employment, then this will be fundamentally different capitalism that would require "new social and political institutions which will reflect the increased power of the working class." If capitalism cannot adjust its mode of operation to this new reality, then "it will show itself an outmoded system which must be scrapped." The new reality was unlikely to lead to fascism, because that had flourished in Germany precisely because of the failure to secure full employment in capitalist democracies. The struggle for full employment in capitalism is a way of preventing fascism. (Kalecki 1943: 331). 


\section{THE ‘EMPLOYER OF LAST RESORT’ AND THE QUESTION OF FINANCIAL CON- TROL}

The financing of 'employer of last resort' proposals is defined by Modern Money Theory. This is essentially a state theory of money, that presents money as a state, or 'sovereign' function associated with the fiscal policy of governments (Wray 2012, chapters 2-4). This provides a political economy without modern capitalism. Banks create credit. But the rest of the economy produces and distributes without monetary effect. Apart from dismissing monetarist theories of inflation, Modern Money Theory is surprisingly vague about the causes of inflation (Wray 2012: 241-258). In similar contrast to Kalecki, the proponents of the policy have little to say about the causes of unemployment, which are supposed to be due to aggregate demand failures without specifying how those failures arise. Further, the literature around the Job Guarantee programme contains virtually no analysis of alternative methods for achieving full employment, that might show up more clearly the advantages and disadvantages of an Employer of Last Resort policy. Kalecki analysed extensively four policy proposals: the standard neo-classical method of lowering wages (in his paper on real and money wages, Kalecki 1939, chap. 3); stimulating private investment, public investment and public welfare such as public services and transfer payments (in his paper Three Ways to Full Employment, Kalecki 1944; see also the paper by Burchardt in the same volume, Burchardt 1944). For the proponents of the Employer of Last Resort policy, there is only one 'Plan' that can only be compared to a state of involuntary unemployment.

Kalecki also recognised that capitalists will be better off under full employment, but that they will have other, political, objections to full employment. Modern Money Theory and the employer of last resort proposal do not incorporate any consideration of the possible reaction by capitalists to full employment. It is as if they recognise the clear economic rationale for such a policy, without bothering themselves about the political implications of the policy. In their literature, the financing of an employer of last resort certainly seems modest, since in their view it would be primarily paid for by the withdrawal of unemployment insurance, which would now be unnecessary. The remaining cost is said to amount to 1 or 2 per cent of Gross Domestic Product, a marginal sum that could be covered by the central bank financing favoured by Modern Money Theory (Wray 2011).

This calculation almost certainly under-estimates the total cost. The trend in recent decades has been to make unemployment insurance payments increasingly difficult to obtain, with applicants having to satisfy means tests to show that they have no alternative means of support, and tests of willingness to work, to prove that they are genuinely involuntarily unemployed. Such tests effectively exclude large numbers of the unemployed, who can survive on the incomes of family or their own savings. This shows up in the data on labour force participation (the proportion of people of working age who are in employment or seeking work), which has fallen substantially over the last two decades.

Even if one overlooks this bias in their calculations, there is a much more fundamental flaw in their monetary analysis. It overlooks the crucial matter of the cir- 
culation of money in the economy. The processes of production and exchange in a capitalist economy concentrate money in the bank deposits of big businesses and the big banks in which they keep their accounts. This is the monetary significance of the differential rates of profit that hold in a capitalist economy, with large oligopolies having larger rates of profit than competitive small and medium-sized enterprises (see Kalecki 1954, chapter 1). Such monetary concentrations would be increased by 'monetisation' of government expenditure. To paraphrase Kalecki, the cry will go up that the situation is 'manifestly unsound' and an unnatural interference in an efficient (full-employment-seeking) labour market. Big business will find more than one economist to adjudicate that the increase in the money supply is inflationary. Even if there is no inflation, economists can be relied upon to provide models that will show inflation accelerating in the future. This simplistic thinking will add to the political difficulties of any employer of last resort programme undertaken by a government. The alarm will be raised among corporations, banks and the rich, that their bank deposits are about to be devalued by inflation. Outside the United States there is only one thing that big banks and their clients can do: convert their bank deposits into bank deposits in a currency deemed to be more secure (the US dollar is the traditional haven in inflationary times). The result will be a currency crisis and the eventual devaluation of the country's currency. That devaluation of the currency, by increasing the cost of imports, will then cause the inflation that was the pretext for the alarm. Workers will demand compensation, and the result will be a wage-price spiral that will confirm the 'irresponsibility' of the government.

It should be pointed out here that the inflation will not be caused by an excess money supply (the monetarist theory), or full employment, but by the dollarization of their assets by capitalists, or 'capital flight'. This capital-flight-driven inflation will then continue until the government abandons its employer of last resort policy. At this point, the rise in unemployment will weaken the drive to win wage increases to compensate for the rise in prices. As real wages fall, unemployment will rise further in the wage goods sector, and this will eventually break the rise in prices. Inflation will be reduced not by a stricter control of the money supply, or fiscal austerity, but by the growth of unemployment, Marx's 'reserve army of labour'.

The exception here is the United States. America's excess liquidity will be ladled into American financial markets, there to cause not so much a renewal of inflation in the economy at large, but financial instability, the responsibility for which can be laid at the door of any radical administration and its 'unsound' monetary practices, exposed by the infallible insights of those 'efficient' financial markets.

\section{CONCLUSION}

The Employer of Last Resort, or Job Guarantee, proposal presents a simple solution to the economic problem of unemployment. In that solution, the government guarantees to employ anyone who cannot find a job in the labour market. The literature putting forward this proposal does not enter into the causes of unemployment that would be overcome by a Job Guarantee, nor does it consider the alternatives that may 
reveal more effective employment strategies. Almost certainly it under-estimates the fiscal costs of such a programme, and its political economy is surprisingly modest, in the sense that it does not take into account the political objections that may arise and the likely political reaction of employers. These are of crucial importance because the suggested financing of the proposal would reinforce the political power of employers.

The Employer of Last Resort proposal assumes the legitimacy of good intentions without considering the constraints that are imposed on policy by the society in which those intentions are to be realised. We live in a class society in which the possibilities of reasonable reform have to overcome the interests of the rich and the powerful, including the oligarchs who claim to be speaking on behalf of the poor and the powerless. While an appeal to the sense of fairness and efficacy of the 'plain man' may be an effective rhetorical strategy, it cannot succeed without taking into account the opposition that Big Business will mount to the threat that full employment poses to its economic prerogatives. In his full employment proposal, Kalecki explained how that opposition would arise. The Employer of Last Resort proposals indicate the fundamental inefficiency in capitalism. However, by comparison with Kalecki's analysis, they are naïve.

FUNDING: This research received no external funding.

CONFLICT OF INTEREST: The author declares no conflict of interest.

\section{REFERENCES}

Burchardt, Fritz A. 1944. “The Causes of Unemployment.” Pp. 1-38 in The Economics of Full Employment, edited by F. A. Burchardt. Oxford: Basil Blackwell.

Gaitskell, Hugh T. N. 1933. “Four Monetary Heretics.” Pp. 346-413 in What Everybody Wants to Know about Money: A Planned Outline of Monetary Problems, edited by G.

D. H. Cole. London: Victor Gollanz.

Kalecki, Michał. 1937b “A Theory of Commodity, Income, and Capital Taxation.” The Economic Journal 47(187): 444-450. https://www.jstor.org/stable/2225357

Kalecki, Michał. [1939] 1980. “Płace nominalne i realne.” Pp. 40-72 in Michał Kalecki. Dzieła. Kapitalizm. Dynamika gospodarcza. Tom 2. Warszawa: Państwowe Wydawnictwo Ekonomiczne.

Kalecki, Michał. 1943. “Political Aspects of Full Employment.” Political Quarterly 14(4): 322-331. https://doi.org/10.1111/j.1467-923X.1943.tb01016.x

Kalecki, Michał. 1954. Theory of Economic Dynamics: An Essay on Cyclical Long-Run Changes in Capitalist Economy. London: George Allen and Unwin.

Kalecki, Michał. [1944] 1979. “Trzy drogi do pełnego zatrudnienia.” Pp. 350-374 in Michał Kalecki Dzieła. Kapitalizm. Koniunktura i zatrudnienie. Tom 1. Warszawa: Państwowe Wydawnictwo Ekonomiczne.

Keynes, John M. 1936. The General Theory of Employment, Interest and Money. London: Macmillan. 
Osiatyński, Jerzy. [1979] 1990. "Przypisy i dodatki.” Michał Kalecki Dzieła. Kapitalizm. Koniunktura i zatrudnienie. Tom 1. Warszawa: Państwowe Wydawnictwo Ekonomiczne.

Wray, L. Randall. 2011. “The Job Guarantee: A Government Plan for Full Employment.” The Nation 27 June. Retrieved September 20, 2019 (https://www.thenation.com/ article/job-guarantee-government-plan-full-employment/).

Wray, L. Randall. 2012. Modern Money Theory: A Primer on Macroeconomics for Sovereign Monetary Systems. Basingstoke: Palgrave Macmillan.

\section{BIOGRAPHICAL NOTE}

Jan Toporowski is Professor of Economics and Finance at SOAS University of London, the UK.

OPEN ACCESS: This article is distributed under the terms of the Creative Commons Attribution Non-commercial License (CC BY-NC 4.0) which permits any non-commercial use, and reproduction in any medium, provided the original author(s) and source are credited.

ARTICLE HISTORY: Received 2019-10-02 / Accepted 2019-11-28 